\title{
Model Employers and Good Government in the Late 19th and Late 20th Centuries
}

\author{
Jeffrey Haydu ${ }^{1,2}$ and Caroline Lee $^{1}$
}

This study compares models of the good employer in the late 19th and late 20th centuries, using a content analysis of leading business periodicals. We find striking differences between the two eras, both in their recipes for more efficient employment practices and in their understanding of the benefits of those practices. We consider possible explanations for these divergent conceptions of "rational" labor relations and argue that each period's image of the exemplary employer corresponds to prevailing ideals of political reform.

KEY WORDS: business ideology; comparative-historical; work and politics.

\section{INTRODUCTION}

Business commentators in the 1980s and 1990s celebrated the virtues of flexible employees, teamwork, and a gung-ho company culture. Organizing work around these principles, they argued, enhanced productivity, fostered innovation, and boosted profits. One hundred years earlier, their counterparts offered a different recipe for handling employees, one which called for a sharper division of labor among taskworkers, clearer rules, and more centralized authority. Our primary goal in this paper is to flesh out this comparison between praiseworthy employment practices in the late 19th- and late 20thcentury business press. As we will see, these ideals differ dramatically between the two periods. The difference lies less in the recommended balance between efficiency and nurturance in handling employees than in the very understanding of what efficient and nurturant management means. Our secondary goal is to propose an explanation for the contrasts between periods.

${ }^{1}$ Department of Sociology, University of California-San Diego, La Jolla, California 92093-0533.

${ }^{2}$ To whom correspondence should be addressed; e-mail: jhaydu@ucsd.edu. 
Here we link advice about the treatment of employees to political discourse. The model employer portrayed in the general business press turns out to have much in common with standards of "good government" advocated by political reformers in each period-a surprising case of cultural isomorphism.

To get the flavor of the data we use and the contrasts we find, consider two examples. In 1990, Business Week lavished praise on Corning Inc. for its commitment to employee education and teamwork. "With extensive on-the-job training, real involvement in decision-making, and good job security," employees at the company's Blacksburg, Virginia, facility "have the right tools and incentives to produce high-quality automotive filters." Selfmanaging teams of broadly trained workers gave Corning flexibility as well as quality, including the ability to "retool a line to produce a different type of filter in only 10 minutes." The system also made it possible to "eliminate several tiers of managers." Corning's approach, finally, made employees more enterprising. "Everybody that works here is competitive," says one enthusiastic employee. "We're willing to work long hours. We want ... to make the product better so we can be the best in quality and service.... I'm responsible for my own job security" (Business Week, December 17, 1990:72-78). A century earlier, Iron Age magazine singled out Excelsior Mfg. Co. for its approach to training. The firm's apprenticeship system selected the most promising boys and educated them for skilled foundry work. The program had several virtues. "Punctuality is insisted on; also good conduct in the works and strict accountability for tools.... Care in workmanship is thus inculcated from the beginning and slovenly habits eradicated." In addition, this apprenticeship system was "entirely independent of the Molders' Union" (Iron Age, August 2, 1883:14-15).

Corning displays traits the business press regularly commended in the last two decades of the 20th century. Good employers foster teamwork, flatten hierarchies, and encourage employees to exercise the creativity-and assume the risks-once associated with entrepreneurs. Excelsior Mfg. was no less committed to training employees. The virtues of its system, however, are almost the opposite of Corning's. Its apprenticeship system produced specialists, not generalists, and rewarded men who followed rules rather than exercised creativity. At Excelsior, unlike at Corning, imparting skill and building moral character went hand in hand. And for Iron Age writers, one of the virtues of a well-trained workforce was to enhance rather than decentralize managerial control. In all these respects, Excelsior is representative of the employers lauded by business periodicals in the last two decades of the 19th century.

Both Corning and Excelsior were admired for their efficient management of employees. The business press in these two eras, however, understood "efficient" labor relations to mean entirely different things. The main 
section of this paper, "Model Employers," explores these differences in more detail. We begin by reviewing the literature on a related topic-changing fashions in management discourse-and ask how closely those fashions resemble employment practices advocated in the lay business press. We then describe our data sources (articles appearing in general business periodicals rather than more specialized journals of management and industrial engineering) and our findings. The following section, "Explaining the Differences," considers possible explanations for the differences we find. Here we follow the same logic as in the preceding section, first summarizing existing accounts of management rhetoric, then assessing their applicability to business ideology, and finally arguing that business discourse about "best practices" at work parallels prevailing recipes for political reform.

\section{MODEL EMPLOYERS, 1880-99 VS. 1980-99}

\section{Management Rhetoric vs. Business Ideology}

Scholarly accounts of trends in management rhetoric provide a good starting point for studying business images of model employers in the late 19th and late 20th centuries. These rhetorics and images are not identical, particularly during the late 19 th century, and this should come as no surprise. The literature on management, however, does provide a useful vocabulary for discussing changing ideas about how best to organize work.

The most systematic surveys of trends in management rhetoric are those of Barley and Kunda (1992), Abrahamson (1997), and Shenhav (1999) (see also Baron et al., 1986; Bendix, 1974; Guillén, 1994; Jacoby, 1985; Kaufman, 1993). Barley and Kunda assign management theories to one or the other of two broad camps, labeled "normative" and "rational" control. The first highlights employees' human needs and social relationships as the keys to both worker morale and labor productivity. An important management task, accordingly, is to make sure workers are properly socialized and committed to the firm. "By winning the hearts and minds of the workforce, managers could achieve the most subtle of all forms of control: moral authority" (Barley and Kunda, 1992:364). The second camp assumes that employees are rational actors and treats them as factors of production. Management's responsibility is to engineer productive resources, including labor, for maximum efficiency. Barley and Kunda present the history of management discourse as a pendulum swinging back and forth between these two poles of normative and rational control. Their narrative moves from industrial betterment (1870-1900) through scientific management (1900-1923), human relations (1925-1955), and systems rationalism (1955-1980) to organizational culture 
(1980-). If this account applies to representations of model employers in the business press, accordingly, we would expect normative themes to predominate relative to rational ones in both 1880-99 and 1980-99.

Abrahamson (1997) affirms both the general categories of normative and rational control and the basic narrative of management discourse alternating between them. But he tinkers with the historical timing and introduces additional subtleties to the characterization of each period. Using business periodical indexes to classify and count articles, he finds that scientific management, welfare capitalism, and organizational culture began their runs slightly earlier than Barley and Kunda claim. He also argues that managerial rhetorics varied in their prevalence after their initial emergence. For example, human relations approaches were eclipsed by systems rationalism in the 1950s. Some of these approaches, however, remained in management's repertoire, waxing and waning in popularity even during an era in which rational control predominated. Shenhav, finally, locates the key breakthrough to "manufacturing rationality" in the late 1890s (Shenhav, 1995, 1999). It was at this time, he argues, that principles of systematization and standardization, already applied to mechanical engineering, were translated into principles of human management. Shenhav's attention to rationalizing themes in the era of "industrial betterment," we will show, is amply warranted.

To what extent do model employers in the general business press conform to these findings about management rhetoric? Do we find the same criteria for the proper treatment of employees? Is there the same preponderance of normative over rational themes in the two periods we focus on? What more specific themes, distinctive to each period, emerge from a closer look at the business press?

Particularly for the late 19th century, there are reasons to expect management rhetoric and business ideology to differ. As Shenhav (1999) notes, late 19th-century management specialists and industrial engineers were beginning to construct a role for themselves distinct from that of the ownermanager (see also Calvert, 1967; Zunz, 1990). Businessmen and proponents of manufacturing rationality, in other words, were apt to be different people. Manufacturers in this period, moreover, proudly labeled themselves "practical men" and frequently expressed skepticism of (or even contempt for) mere theorists, including self-proclaimed "scientific" managers like Frederick Taylor (Nelson, 1975). ${ }^{3}$ As compared to high-profile magnates like Rockefeller or voluble management experts, however, we know much less

\footnotetext{
${ }^{3}$ That skepticism lives on. Articles appearing in contemporary business magazines, showcasing a firm's good labor relations, commonly distance themselves from management fads and from impractical academic rostrums. This or that technique, the article is apt to say, is all the rage, but in this case it really works to meet company goals.
} 
about the views of these proprietors. It is worth learning more, because labor practices in small- and medium-size firms affected far more workers than those of large firms staffed with "welfare secretaries" or production engineers (Brandes, 1976; Ramirez, 1978). General-circulation business magazines should reflect these employers' views better than the more specialized periodicals (such as the American Machinist or Engineering) examined by Shenhav or the "clergy, journalists, novelists, [and] academics" whom Barley and Kunda (1992:365) cite as championing industrial betterment. These magazines may also have helped shape business opinion by giving wide circulation to stereotyped models of good employment practices.

We anticipated that our findings on model employers in the business press would differ from scholarly treatments of management rhetoric for another reason. Given the interest of Barley and Kunda or Abrahamson in general patterns of change, it may make sense for them to lump management rhetoric into the two broad categories of normative and rational control. To measure shifts between these two categories over time, it is also reasonable to rely, as they do, on the subject tags assigned to articles in business periodical indexes. We are more concerned with historically specific characteristics of the model employer, including the very different ways in which business writers in the two periods understand "rational" management. For that purpose, it is essential to get underneath subject tags to the specific language of praise for model employers.

\section{Data Sources}

To do so, we conducted a content analysis of full articles in leading business magazines that profiled model employers in each period. Because of our suspicion that ordinary businessmen and professional managers or management theorists had different views of desirable employment practices, we selected journals addressed primarily to the business community rather than more specialized audiences. We also sought periodicals with substantial circulation and with wide coverage rather than a focus on trade-specific news. For employers from different industries, magazines such as these would be a common source of conventional wisdom about the treatment of workers. These journals are hardly reliable sources about actual management practices (Ferguson, 1989). Our interest, however, is not in the factual accuracy of these accounts of good employers, but in the rhetorical formulas that they use.

Ideally, we would have used journals that had a continuous existence through both periods, thus improving the chances that any differences we identified were the effects of periods rather than journals. Unfortunately, 
there are no general business periodicals published through both periods. Instead, we chose two magazines from each period and found that, at least within each period, there were no noticeable journal effects in portrayals of model employers. For 1980-99, Business Week and Fortune were obvious and readily available choices. For $1880-99$, the pickings were slimmer. Some plausible journals were published only for part of the period; others proved unavailable. In the end, we settled on the Commercial and Financial Chronicle and Iron Age. The Chronicle was a periodical comparable to today's Wall Street Journal, providing information to readers on financial markets, industry and trade conditions, and government activities relevant to business. It also had reports on specific firms, and some of these highlighted employment practices (Steeples, 2002). Iron Age attended more to manufacturing, and (its title notwithstanding) it covered a wide range of industries. For our purposes, Iron Age also has the advantage of having had editors and owners aligned with proprietary firms rather than larger corporations like Carnegie's (Ingham, 1991; Mapes, 1973).

All four journals are well indexed, making it easy to cull promising articles for a closer look. Articles from Iron Age and the Commercial and Financial Chronicle that included praise for employment practices are neither so long nor so numerous as to require sampling. We used all 87 pieces for 1880-99. Articles in Business Week and Fortune are much longer and more often focus on labor relations. To draw a manageable sample, we limited selection to articles focused on a single firm and primarily concerned with employment practices. We then took a random sample of these to yield a matching 87 substantial pieces for $1980-99$.

Next, we developed a coding scheme, beginning with broad themes discussed in the secondary literature on management discourse. As is usual with content analysis (Roberts, 1997; Weber, 1990), we elaborated and refined the scheme as we went back and forth between conceptual categories and empirical examples. This involved adding new items, regrouping (putting "participation" under "good governance" as against "fostering opportunities," for example), and subdividing (distinguishing between individual and collective participation, e.g., suggestion boxes as against quality circles) until the scheme seemed to capture all the themes we found and to pigeon-hole them in sensible ways. We also collected other information from each article, such as the industry, company size, who was given credit (e.g., an owner? a manager?), and what other sorts of virtues, besides good employment practices, were attributed to the company (such as philanthropic activities or technical innovations). To illustrate our general classification of themes, we include the first two levels of the final scheme in the Appendix. ${ }^{4}$ We did the

\footnotetext{
${ }^{4}$ The complete list of subcategories is considerably longer. It is available from the authors.
} 
final coding independently. We found few differences between these assessments, and we reconciled those that did occur.

\section{Findings: Model Employers in 1880-99 vs. 1980-99}

Two common themes in the business press's profiles of model employers match the management rhetoric surveyed by Barley and Kunda. Praiseworthy employers in the 1880s and 1890s promoted "industrial betterment," and their counterparts a century later enhanced the firm's "organizational culture." Business commentators in the late 19th century most frequently highlighted amenities that enhanced employees' lives outside of work $(18.4 \%$ of articles) or welfare benefits on the job (17.2\%). Common welfare measures include pension plans, accident insurance, and medical care. The amenities might be as simple as an annual dinner, or considerably more ambitious. Cornelius Vanderbilt, for example, was commended for erecting "a home where railroad employees can spend their leisure time with profit and pleasure. Not only is there a library and a reading room, but there are rooms for social conversation and recreation.... It is very desirable that men should be helped to take a noble and higher view of life, and this is accomplished ... by investing them with more favored surroundings" (Commercial and Financial Chronicle, October 8, 1889:453).

For the late 20th century, the business press similarly supports Barley and Kunda's characterization of prevailing management rhetoric as favoring "organizational culture." Model employers in this period are most often praised for building esprit de corps among employees or otherwise enhancing the company culture, themes that appear in $32.2 \%$ of the sample. United Parcel Service, for example, is commended for "instill[ing] a spirit of winning so pervasive that people who fail are ranked as least best, not losers. Workers, in turn, have almost a Japanese-like identification with the company," with its "half Marine Corps and half Quaker meeting" culture (Fortune, January 18, 1988:56-58). Almost as common in accounts of model employers is "teamwork" (31.1\%), tied for second among employer virtues. At Bell Atlantic, CEO Raymond Smith encourages employees to "feel more like participants than victims." "True believers" at the firm "wear "Coach Me' buttons, an invitation to co-workers and even subordinates to offer advice" (Business Week, December 2, 1991:133, 135).

These themes in the business press are also consistent with Barley and Kunda's more general characterization of management rhetoric in the two eras as favoring "normative control." Model employers of both eras attended to employee needs and relationships, and they saw improvement in this area as the key to meeting company goals. Such depictions of good employers in 
the two periods also proved remarkably stable. We detected no change in the prominence of various themes within each period.

Portraits of the model employer diverge from findings in studies of management rhetoric in the balance they strike between normative and rational themes. In both periods, the business press's model employer is nearly as concerned with rationalizing work as he is with cultivating employee needs. The good employer of the late 19th century, to begin with, had a harder edge. The third most common theme in this period was praise for the rule of law at work. In $16.1 \%$ of the articles, companies are lauded for routinizing the handling of employees. "A good boss," Iron Age opines, "will not show partiality, but ever stands independent and in a position to say no or yes, or discharge any person upon the 'spur of the moment' for a just reason. He will have higher principles than tolerating clannishness ... or favor, but will endeavor to do justice to all" (December 21, 1893:1116). Although this advocacy of systematic discipline was sometimes rooted in concerns over "bullying" foremen, it also reflected a desire to tighten control and reduce "personal" considerations in employee management (Nelson, 1975). "Rationalizing" concerns also appear in praise for employee training programs like that seen at Excelsior. Such programs (noted in $12.6 \%$ of the articles, tied for fourth most common) had more to do with improving the technical proficiency of employees than they did with their social needs and morale. Indeed, discussions of training schemes are often prefaced by a ritual lament over the decline of traditional apprenticeship and the corresponding need to increase supplies of skilled labor-an argument clearly treating workers as a resource to be procured, not as human beings in need of "betterment."

During 1980-99, similarly, a preoccupation with efficiency and productivity is about as common as solicitude for company culture. As noted, company culture and teamwork are at the top of the list of employer virtues. But just as common as teamwork are policies that encourage individual entrepreneurship among employees. Almost a third (31.0\%) of the articles commend firms for giving employees more independence to do their best and for pushing them to assume the risks of doing so. Johnson \& Johnson "encourages people to take risks, creating a corporate culture where even mistakes can be a badge of honor." Nor does this firm rely only on its corporate culture to foster individual risk-taking. Its $\mathrm{CEO}$ is praised for "a bonus program that will reward entrepreneurial accomplishments and strong performance with cash" (Business Week, September 26, 1988:126-127). Here we see assumptions about individual rationality and self-interest more commonly associated with "rational" control. And here too, there is a harder edge to employee empowerment. The opportunity to succeed goes hand in hand with the chance to fail. At Lincoln Electric, "each employee is accountable for the quality of his or her own work and is rated twice a year on quality 
[and] output." Bonuses may be generous for good work, but "how much you make is in your own hands" (Business Week, January 22, 1996:89).

In both periods, then, business representations of the good employer emphasize the importance of rationalizing production as well as improving human relations. This is hardly surprising. By focusing on the business press, we deliberately give less weight to the views of other commentators, whether clergymen and welfare secretaries in the late 19th century or personnel managers and academics in the late 20th. As compared to those sources, the business press would be expected to highlight measures that speed production, improve quality, and cut costs. More surprising is the stark difference in the two periods' conceptions of what specific employment practices are most likely to improve efficiency-what more "rational" management actually meant. In brief, the good employer of the late 19th century sought to make work more bureaucratic; his late 20th-century counterpart sought to make it less so.

We noted that one key theme in profiles of good management in the 1880 s-90s is the rule of law. Commentators frequently allude to this concern in their descriptions of the increasing size of plants and the inability of employers to maintain the "personal touch" with workers (Mandell, 1997; Marchand, 1998:101-102). They also warn that arbitrary or abusive foremen could incite conflict or drive the best employees to quit. This is the backdrop against which Iron Age and Commercial and Financial Chronicle commentaries recommend more systematic supervision, with fixed rules clearly posted and consistently applied. The Chronicle lauds several railroad companies, for example, for their "more rational system of discipline.... This is commonly known as the Brown system of discipline, and is based on a record being kept of each employee, ... and promotion or perhaps ultimate dismissal is governed by the record of the special failures or merits" (November 25, 1899:6). ${ }^{5}$ Praise for this kind of system appears in $16.1 \%$ of articles on good management, as compared to $1.1 \%$ during the late 20 th century. It is an agenda that goes with other kinds of bureaucratization. Good employers of the period adopted clear rules for hiring new employees and for governing their job performance; relied more on experts or specialists in managing workers; moved effective decision-making authority up to more responsible company officials; and clarified the division of labor between different jobs or departments. ${ }^{6}$ Such practices win praise in $19.5 \%$ of the 1880 99 articles, compared to $6.9 \%$ of the 1980-99 sample. The general spirit of these recommendations is clear from Iron Age's enthusiastic profile of Brown and Sharpe's foundry, where "the working of the men has been thoroughly

\footnotetext{
${ }^{5}$ Hence the contemporary expression "Brownie points."

${ }^{6}$ For the realities corresponding to this rhetoric, see Jacoby (1985).
} 
systematized, and everything is done with perfect regularity. No castings are made without a written order from the foremen of the different departments requiring them. These orders are all kept on file.... When castings are furnished, they are checked off with a memoranda of the date delivered, thus preventing all disputes about parts which are broken or lost. Everything moves without that 'hurrah boy' style noticed in many foundries" (February 16, 1882:1).

The approach advocated 100 years later is strikingly different. Here we find praise of teamwork and an engaging company culture. Moreover, we find persistent advocacy of employment practices that reverse bureaucratization. Instead of consistently applying fixed rules, the good employers cited in Business Week and Fortune involve their workers in decision making (50.6\% of articles, as against $3.4 \%$ in 1880-99). At Westinghouse's Pittsburgh facility, according to Fortune, "Bosses in the construction group don't simply issue orders; they seek consensus. Out in the factories, foremen don't bellow coarsely at workers-at least they aren't supposed to; they ask for suggestions" (June 15, 1981:74). A related virtue often celebrated in the late 20th century is decentralized authority. One commonly admired practice, for example, is to cut out one or more layers of the management hierarchy (13.8\% of articles vs. none). In an article commending Matsushita's "radical restructuring," Business Week reports that the CEO had "eliminated an entire layer of management at headquarters," reassigning many of them to take more direct responsibility for product development. "This restructuring has transformed division chiefs into entrepreneurs" (October 31, 1994:109). Another recommendation is to rely less on formal rules to regulate work, on the grounds that enumerating rules results in stultifying red tape $(5.7 \%$ of articles, as compared to $1.1 \%)$. A third component of this antibureaucratic ideal favors individualizing rewards for work performance, as against the late 19th-century advocacy of equal treatment for all employees $(19.5 \%$ of articles, in contrast to $1.1 \%$ in $1880-99){ }^{7}$ Here too, support for practices such as giving bonuses for superior job performance is clearly related to the more general revival of entrepreneurial ideals. Finally, instead of praising specialized training and expertise, the late 20th-century business press celebrates "flexibility" (for the standard academic account of this reorientation, see Piore and Sabel, 1984). Unpacked, flexibility is at odds with bureaucratic virtues in several ways. One common recommendation favors cross-training and job rotation (17.2\% of articles), not specialization and a more finely graded division of labor. At GM's Packard Electric, some workers "have

\footnotetext{
${ }^{7}$ Already in the 1890 s, management consultants are recommending various plans for increasing output by paying for results (Schloss, 1898). At least in the period examined, however, this approach appears in only 1 out of the 87 articles on good employers.
} 
Table I. Major Themes in Business Press Articles, 1880-1900 and 1980-2000

\begin{tabular}{lcc}
\hline & $1880-1900^{a} \%(n)$ & $1980-2000^{b} \%(n)$ \\
\hline Normative themes & & \\
$\quad$ Welfare measures (any kind) & $44.8(39)$ & $14.9(13)$ \\
$\quad$ Participation, teamwork & $3.4(3)$ & $50.6(44)$ \\
Rational themes & $19.5(17)$ & $6.9(6)$ \\
$\quad$ Bureaucratize, the rule of law & $5.7(5)$ & $60.9(53)$ \\
$\quad$ Decentralize, improve flexibility, & & \\
$\quad$ foster entrepreneurship & & \\
${ }^{a} N=87$. & \\
${ }^{b} N=87$.
\end{tabular}

been trained in statistical process control and use this technique to improve product quality." On the assembly line, "operators work in teams, rotating jobs" (Business Week, August 29, 1983:55). Good employers also eliminate rigid work rules and reduce the number of job classifications (12.6\%). An additional $8.0 \%$ of articles praise flexibility in more general terms. None of these themes appear in representations of the well-managed workplace of the late 19th century. The major contrasts between the two periods are summarized in Table I, aggregating specific themes into broader categories.

One additional contrast emerged clearly in representations of good employers. In both eras, the business press often stresses that praiseworthy employment practices are not merely good in themselves; they also have ancillary virtues or, as late 20th-century writers would say, payoffs. The desirable payoffs in the two periods were very different, however. About half the articles in 1880-99 link good management of workers to some other benefits. In $56.1 \%$ of these cases, the benefit is to reduce strikes or other forms of conflict at work. In another $29.3 \%$, the payoff is to improve the personal morals of the workforce. In the 1980-99 model of employment management, conflict reduction is rarely mentioned; improving morale receives even less attention; and enhancing employee morals is not mentioned at all. Instead, even the most nurturing of management practices are presented as contributing to the company's profitability (47.8\%), spurring technical innovation $(32.6 \%)$, or increasing productivity (30.4\%). In effect, business writers in both time periods have their bottom lines. In the late 19th century, however, the bottom lines include social and moral ends; a century later, the market rules. Table II summarizes these contrasts.

Our findings, then, complement studies of management rhetoric in several ways. First, we find that business press portrayals of model employers are more balanced as between rational and normative themes than are the management rhetorics studied by Barley and Kunda and by Abrahamson. Second, our comparison highlights the starkly opposed conceptions of "rational" employment management in the two eras, a contrast that is less apparent 
Table II. Ancillary Benefits of Model Practices Mentioned in Business Press Articles, $1880-1900$ and $1980-2000$

\begin{tabular}{lcc}
\hline & $1880-1900^{a} \%(n)$ & $1980-2000^{b} \%(n)$ \\
\hline Conflict reduction & $56.1(23)$ & $5.7(3)$ \\
Employee morals & $29.3(12)$ & $0(0)$ \\
Profitability & $0(0)$ & $73.6(39)$ \\
Technical innovation & $4.9(2)$ & $35.8(19)$ \\
Productivity enhancement & $7.3(3)$ & $43.4(23)$ \\
\hline
\end{tabular}

Note. Ns are smaller than in Table I because we are reporting only on those articles that noted some additional payoffs from good employment practices. ${ }^{a} N=41$.

${ }^{b} N=53$.

in studies that highlight the shared normative character of late 19th- and late 20th-century management rhetoric. A closer look at the details of business writers' praise of good employers also reveals how rational management was thought to have different payoffs. In the first period, it promised moral improvement; in the second, economic gains.

\section{EXPLAINING THE DIFFERENCES}

For the purposes of this paper, our primary goal is to tease out differences between the model employer of the two periods. More briefly, we also propose an explanation for those differences: that the distinctive features of each period's model employer mirror currents in political reform. This is a deliberately guarded formulation. We do not claim that prevailing ideals of good government causally determine beliefs about good employment practices. It is much more likely that influence runs in both directions, or that both sets of ideals reflect common responses to historical conditions, whether they be widespread social unrest in the late 19th century or an acute sense of national decline following the 1960s. Our goal in this final section is not to identify first causes. Instead, it is to identify a surprising case of isomorphism: in both periods, ideals of governance in the state and the workplace are remarkably similar. Here too, it is useful to compare our account with studies of management rhetoric. Those studies offer plausible explanations for general currents in managerial thought, but they are less helpful once we turn to historically distinctive characteristics of the model employer in the business press.

\section{Management Rhetoric vs. Business Ideology}

In their study of management rhetoric, Barley and Kunda argue that rational and normative forms of control correspond to rival solutions to the 
problem of order. The two approaches are specific instances of the more general polarities of Western culture, as between associative and communal ties or between individual self-interest and collective integration. The swings of the pendulum between rational and normative control reflect successive backlashes against reigning management orthodoxies. The specific timing of these swings, in turn, corresponds to the phases of expansion and slowdown in long economic cycles. In periods of expansion, management focuses on harnessing new, foundational technologies and organizational innovations. As these new techniques face diminishing returns, managers turn to human capital as a way to further increase productivity. In the case at hand, the late 19th and late 20th centuries were both eras in which older forces of production were exhausting their potential for growth, and new ones had not yet come to the fore. Normative control was the corresponding managerial rhetoric. Abrahamson (1997) largely agrees with Barley and Kunda's account of the emergence of new rhetorics, although he adds that their subsequent prevalence is shaped by such strategic circumstances as government policy and labor union activity.

Shenhav (1999), focusing on late 19th- and early 20th-century rhetoric, is more concerned with the historically specific roots of "manufacturing rationality" in this period. And in contrast to Barley and Kunda, he attributes management rhetoric to specific historical actors: industrial engineers, with their particular occupational culture and professional ambitions. The preoccupation of early 20th-century industrial managers with standardizing and systematizing labor relations, Shenhav argues, applied the logic of mechanical engineering to employees - and created well-paid jobs for these "experts." They were able to gain acceptance for these views (and jobs), Shenhav adds, because of certain political conditions. Turn-of-the-century worker militancy gave engineers an opportunity to sell their managerial nostrums as solutions for "the labor problem."

These accounts of management rhetoric are of less value in explaining business representations of the model employer. Barley and Kunda are interested in the shared normative character of late 19th- and late 20thcentury management rhetoric, and so they also search for causal factors that the two periods have in common-a particular stage in long-term economic cycles. Business writers, however, recommend sharply contrasting employment practices in the two eras, and they highlight quite different benefits from those practices. For understanding these differences in the model employer, Barley and Kunda's study of managerial rhetoric offers little help: similarities cannot explain differences.

Shenhav is also more interested in organization theory than the details of the model employer. And particularly in the 1880-99 period, professional engineers cannot be seen as the source of business definitions of 
best practices at work. Their influence, Shenhav suggests, came mainly after the turn of the century. And as Shenhav and others (Calvert, 1967; Cochran, 1972; Nelson, 1975) have noted, businessmen of the late 19th century were quite skeptical of the new breed of management consultant, seeing them as mere theorists and as taking ideas of "system" to impractical extremes. Shenhav sets a good example in two other respects, however. First, he identifies a particular social carrier for emerging ideals of systematic management. We will argue that a different social group stood behind models of the good employer. Second, Shenhav joins Guillén (1994) in stressing the importance of politics. We agree, but will emphasize forms of politics other than those highlighted by Shenhav and Guillén.

\section{Business Ideology and Political Reform}

The general account we propose is that contrasting conceptions of the model employer correspond to historical differences in political discourse. We particularly stress the parallels between model employers and fashions in political discourse. In brief, key themes in models of the good employerwhether that of "system" in the late 19th century or of "flexibility" 100 years later-turn out to be part of the common currency of elite political reformers in each era. The kind of politics that matter, in this account, may be clarified by way of contrast to other arguments about the "political" roots of management rhetoric.

Shenhav $(1995,1999)$ offers a good place to start. In his account of the rise of manufacturing rationality in organization theory, class conflict is the kind of politics that matters most. ${ }^{8}$ The intensity of industrial conflict in the late 19th and early 20th centuries, together with widespread employer alarm over worker militancy, gave professional engineers a strategic opportunity. They could (and did) sell their vision of system and standardization at work as a solution for the labor problem. Guillén's comparative study of "models of management" highlights a different kind of politics (Guillén, 1994). The appeal of scientific management and human relations theory in U.S. management thought reflected, among other things, a liberal democratic regime. This political setting forced American employers to be more self-reliant in coping with labor unrest than their counterparts in corporatist Germany. Dobbin (1994) proposes yet another kind of political influence on economic thinking. Political institutions, he argues, provide powerful templates for more general understandings of rational behavior. Although his case study highlights the use of such templates for conceptualizing and

\footnotetext{
${ }^{8}$ In his larger narrative, Shenhav also considers the impact of Progressivism on early 20thcentury management rhetoric. We find that many of the central tenets of Progressivismparticularly its embrace of "system" and its repudiation of partisan politics—are already clear in portraits of model employers in the 1880s, before the "Progressive Era."
} 
solving problems of economic policy, they could be equally potent in shaping businessmen's construction of "rational" employment practices.

For the purposes of explaining differences in models of the good employer, we combine elements from each of these conceptions of politics. As in Shenhav's treatment of organization theory, we emphasize that behind popular business depictions of exemplary employers are social groups acting in a wider political context. That political context, for Shenhav, is class conflict; we join Guillén in casting the causal net more widely. Where Guillén highlights the general character of state intervention, however, we zero in on political reform movements whose scripts also underlie evaluations of the good employer. We share with Dobbin, finally, an interest in the use of common templates across the boundaries between political and economic life. But we trace these templates not to state institutions but to political movements as they frame social problems and advance particular solutions. This adaptation of Dobbin has the advantage of accommodating changes in the character of model employers, because it connects standards of "rational" practice not to more or less fixed political institutions but to shifting fashions in political reform.

Bringing these political themes together, then, we will illustrate the common templates underlying business images of the good employer and reform ideals of good government in each era. Further, we will suggest that particular actors helped transmit these templates back and forth between politics and work. Especially during the late 19th century, businessmen took a close interest in local government and political movements as well as industrial management (Blackford, 1993; Hays, 1964; Wiebe, 1962). And businessmen's wider community networks provided channels through which political and managerial discourse could align. Similar public involvements and networks have been found at the national level in the late 20th century (Akard, 1992; Schwartz, 1987; Useem, 1987). This historical point has a broader theoretical implication. Students of isomorphism have asked why cultural scripts are sometimes transposed from one institutional setting to another (Clemens, 1997; DiMaggio, 1997). We are suggesting that businessmen's civic roles and social networks made them particularly effective carriers of scripts across institutional boundaries. ${ }^{9}$

\section{0-1899: Efficiency, Character, and Good Government}

The three decades after the Civil War brought rapid industrialization, urbanization, and immigration to the United States. Those changes posed political challenges to established elites that went well beyond industrial

${ }^{9}$ For class-conscious businessmen as agents for transposing cultural logics across social domains in the late 19th century, see Haydu (2002). 
class conflict. Local, largely WASP notables raised the alarm over all kinds of social disorder and cultural decay, from undisciplined immigrants and fractious workers to immorality and crime in the city (Beisel, 1997; Boyer, 1978). They also complained that municipal governments were unable to handle these problems or even to manage the basic tasks of extending city services like sewer lines and police protection to new suburbs. What tied these challenges together was political corruption. It was especially among the ignorant and foreign masses that party machines and political bosses found their strongest support. Thanks to this political base, in turn, city politicians winked at vice, ignored the needs of affluent suburbanites, and squandered on propertyless constituents tax dollars paid by the respectable classes (Fox, 1977; Schiesl, 1977).

What remedies did these disenchanted elites-the so-called mugwumps-offer? Above all, they called for good government, and their recipes look like those for good employers. To restore efficiency, integrity, and order to local communities, reformers championed three general principles. Municipal government should be run along more bureaucratic lines, the rule of law should be enforced, and men of "good character" should take the lead (on late 19th-century political reform movements, see Buenker, 1973; Hofstadter, 1955; Miller, 1968; Wiebe, 1962). The bureaucratic ideal included, above all, meritocracy and nonpartisanship in local government. The civil service reform associations formed in many U.S. cities during the 1870s and 1880s demanded that city offices be filled on the basis of merit, not patronage. Political reform clubs also advocated greater reliance on appointed experts, such as city managers or school superintendents, as against board members chosen for party loyalty or political popularity. Once in office, moreover, these qualified men should enjoy civil service protections, so that they would be insulated from the politics of the day. Such measures, it was hoped, would increase municipal efficiency—often referred to as putting city government on a "sound business basis." It would also undercut the power of corrupt political machines. This agenda for neutral bureaucratic administration mirrors that seen at work. In both arenas, the goals include more systematic, merit-based hiring and a shift in authority to more expert managers. And in both settings, reforms would curb the power of lowerlevel, "partisan" functionaries-whether the party hack or the foreman who played favorites and exercised petty tyranny in the shop (Nelson, 1975).

Efficient city government, standing "above politics," was one antidote for urban social problems. Political and economic elites also joined together in calling for "law and order" (Bonnett, 1956; Ross, 1985; Watts, 1991). They were motivated by labor insurgency (above all, the strike waves of 1877 and 1886), but also by a sense that urban crime and civil unrest had overwhelmed city police and courts. The solution was strict adherence to and enforcement 
of the rule of law by more professional police forces, a more principled judiciary, and political leaders who refused to make exceptions for special interests. Again, the approved political reforms parallel businessmen's emphasis on the rule of law as an essential ingredient of good employment management.

Finally, reformers of the day, and especially the patrician "mugwumps," drew a direct link between better government and moral character (Sproat, 1968; Thelen, 1972). Measures to educate and uplift immigrants and ignorant laborers were an explicit part of the solution for urban disorder. And the best hope for local governance was for the "best men" of the community to step forward and assume leadership. Mere change in administrative machinery would not suffice. "Until the men of character and of property can be aroused to suitably take care of their own affairs there appears little to be derived from a change in method[s]" (Cincinnati Enquirer, November $22,1890)$. Thus, the connection made between proficiency and moral character in portraits of enlightened management mimics that found in political reform circles.

In connecting ideals of good governance in politics and in management, we deliberately avoid any strong claims about causal sequencing. Most likely, both managerial and political discourse belong to a common ideological movement. But whatever the ultimate source of these ideals, we know that there were channels for mutual influence, social networks through which ideological clichés could travel between political and business circles. In late 19th-century industrial cities, political reformers and economic elites were often one and the same. Political reformers and businessmen were also closely tied through shared membership in local civic committees, civil service associations, and municipal betterment clubs, as well as cultural institutions and elite social clubs (see the case studies of New York (Beckert, 2001), Chicago (Horowitz, 1976), Cincinnati (Miller, 1968), Pittsburgh (Ingham, 1978), Wilmington (Hoffecker, 1974), Providence (Gilkeson, 1986), and Harrisburg (Eggert, 1993)).

This argument for a link between reform-minded urban elites and a bureaucratic ideal in both politics and the workplace echoes the logic, if not the substantive findings, of Shenhav's account of manufacturing rationality. He traces claims to objectivity and system in management rhetoric to the professional interests and ethos of engineers. And it is clear that this professional group helped spread norms of efficiency and "scientific" management during the Progressive Era (Haber, 1964; Noble, 1977). Even earlier, however, business conceptions of the model employer also celebrated administrative rationality, the rule of law, and objective authority. The social carrier for this ideal was not a new profession but an older elite. In championing bureaucratic efficiency and nonpartisan rule, these mugwumps were defending their 
own positions as leading citizens of their communities. It was good character and social standing, moreover, rather than specialized training or expert knowledge, that guaranteed objective, "businesslike" authority in local governance. The fact that these men of character and substance were mostly prominent local businessmen enabled this ideal of meritocracy, the rule of law, and administrative efficiency to be as readily applied to workplace governance as to municipal politics.

\section{0-1999: Less Government as Good Government}

In the late 20th century, too, political responses to perceived social problems popularized many of the themes that appear in business praise of the model employer. Ronald Reagan's 1980 election is a convenient marker of a larger political backlash against "liberalism." This backlash featured a nowfamiliar diagnosis of national ills and a standard set of solutions (Edsall and Edsall, 1991; Fraser and Gerstle, 1989; Kazin, 1995; Phillips, 1983). America, in this view, suffered from both economic and social decline. Since the 1973 oil embargo, the country's slow growth and high inflation had defied liberal economic orthodoxy. Over the same period, the nation had drifted even further from traditional moral standards and religious certainties. Among the signs were perceived increases in teen pregnancy, unwed motherhood, and drug abuse; persistent welfare dependency; and deteriorating schools. And for both economic and social troubles, conservatives found a common cause: big government. The Great Society had failed. Worse, government regulation was itself a major drag on economic performance, while the welfare state subsidized indolence and irresponsible sexuality. This general critique, hardly new in the 1980s, gained in public attention and legitimacy with the victory of the "new Republicans" in 1980 and in subsequent elections.

Like the alleged ills, the proposed cures became staples of political discourse. Here we can see how recipes for better government parallel journalistic portrayals of the good employer. The typical prescription for government reform called, first, for deregulation (Derthick and Quirk, 1985; Howard, 1994). Reducing the power of federal bureaucracies like the Environmental Protection Agency and the Occupational Safety and Health Administration would reinvigorate a market economy. As in the workplace, part of this reform vision involves relying less on formal rules-the abhorred "red tape," whether that of government or corporate bureaucracy, that blocks productivity and innovation. Unfettered markets, by contrast, ensure that social tasks will be accomplished more quickly and cheaply. Deregulation involved more than an aversion to formal rules and an abiding faith in the ability of the free market to achieve efficiency. As in accounts of the model 
employer, the very measure of successful government reform is provided by markets (rather than by the moral character of citizens or employees). The use of cost-benefit analysis to guide regulatory policy, as mandated by Reagan in 1981, is symptomatic. Proposed regulations merited approval only to the extent that their benefits (such as reducing deaths and medical costs from brown lung disease among textile workers) could be commodified, calculated, and found to exceed the economic costs of government intervention (Stockman, 1986).

Even the most committed Reaganite allowed that some government functions would remain essential. But as far as possible, they should follow a second prescription: decentralization. In matters of welfare policy, for example, decision-making and administration were best left to state and local governments or, where possible, to private contractors (Osborne, 1988). Here too, the parallels to the model employer lie both in the recommendations and the rationale for reform. In both spheres, the call is to rely more on local initiative than on central authority, and the underlying rationale is that decentralization enhances flexibility. Assigning responsibility for welfare programs to states and cities, for example, lets them adapt better to local circumstances, much as "flexible specialists" can nimbly respond to market conditions. More, having welfare policy designed by 50 states rather than one bureaucracy, with incentives for saving money built into federal "block grants," would foster innovative and economical approaches to public assistance. The virtues of decentralization merge here with the goal of empowering markets. Much as the model employer turns wage earners into "entrepreneurs," so with good government. By forcing schools, for example (whether traditional public schools, charter schools, or schools managed by private contractors), to compete for "business" (children or, many conservatives hope, voucher dollars), the government can deliver better and cheaper education. And much as with entrepreneurial initiatives within the corporation, so with government reform: efficiency is closely linked to discipline. Deregulation and decentralization of welfare foster innovation and save money, but they also provide an alternative to reforming moral character. Exposing welfare recipients to the salutary discipline of the market will goad them into working hard and living right.

As in the late 19th century, there is no one-way causal influence from political backlash to model employer. These are both parts of a more general ideological shift, one in which political and economic actors and discourse overlap. Consider one recent account of the rise of the New Right. McGirr's case study of Orange County, California, finds that the backlash against liberalism had two main constituents (McGirr, 2001). At the grass roots were conservative Protestants. Providing leadership and funding, however, were entrepreneurial capitalists, such as developers, small businessmen, and 
subcontractors for the defense industry. As these two strands came together in the late 1960s, the older, more marginal conservativism of groups like the John Birch Society evolved into a more mainstream political critique. Instead of denouncing every act of government intervention as a sign of communist conspiracy, activists criticized the burdens of federal regulation and centralization. In this way the movement also acquired a broader base, illustrated most dramatically by Ronald Reagan's successful 1966 run for California governor. The political movement denouncing big government and celebrating the market, then, had some roots among entrepreneurs themselves. But it also acquired a broader political base and bequeathed a political language that would later influence a different set of economic elites. One key to the "Reagan revolution" on a national scale was that leading corporate executives repudiated New Deal orthodoxies. They did so in the face of stagflation and global competition (Fraser and Gerstle, 1989). But they could draw on rhetorical tools made ready by prior conservative politics, and they could ally themselves with more traditional antigovernment, small-business activists. There were, finally, well-established channels for mutual influence. In the late 19th century, local civic committees and clubs lubricated the movement of ideological frames between politics and business. One hundred years later, national institutions like the Business Roundtable played a similar role (Akard, 1992; Edsall, 1989).

\section{CONCLUSION}

Our main goal in this paper has been to show how differently key members of the business community - writers for leading business periodicalsunderstood what it meant to be a good employer in the last two decades of the 19th and 20th centuries. Above all, one finds a sharp contrast in recipes for efficiency. The agenda for progressive employers in the late 19th century was a bureaucratic one: they sought to make personnel management more systematic, rule-bound, and centralized. A century later, the catchwords are flexibility, participation, and decentralization. In addition, the concern in the 1880 s and 1890 s with reforming employee morals has few echoes 100 years later, while the latter period has its own preoccupation with fostering entrepreneurship among corporate employees. These images of the model employer do not reveal the same preponderance of "normative" over "rational" strategies that students of management rhetoric have described for these two periods. What our data highlight instead is how dramatically the substance of rational and normative control varies with the historical setting.

A secondary goal has been to explore possible explanations for these differences. We showed that the rhetoric of good employee management 
parallels political ideals of good government. Dominant reform movements in each period expressed the same key themes that appeared in business commentary on employers. Reformers of the 1880s championed administrative rationalization, centralized authority, and the rule of law. They also saw moral character as both a source of legitimate public authority and a desirable result of good government. Their counterparts 100 years later called for decentralized and more flexible government. In this vision, entrepreneurship was the main agent of renewal, and market outcomes were the measure of success. Whatever the ultimate source or causal priority of these ideals, we pointed to channels for mutual influence in each period, social networks through which a common conventional wisdom could travel between political and business circles. To use the more sociological language of isomorphism, businessmen were particularly effective vehicles for transposing cultural scripts across institutions.

Although we have focused more on the descriptive task of showing the differences between model employers than on the task of explaining those differences, further research is warranted on both fronts. Our examination of model employers is restricted to two 20 -year periods. It would be useful to compare other eras, ${ }^{10}$ both to see how closely business opinion matches what we know of fashions in management theory, and to see if business views change in tandem with currents of political reform. This agenda has at least three virtues. It promises to enrich our knowledge of variations in the historical construction of "rational" employment practices. It might also confirm an argument that we have only suggested: that political movements, along with Shenhav's professionals, may provide backing for what employers accept as rational practice, whether that be the backing of moral character or market norms. More broadly, it would focus greater attention than sociologists of work have paid to the movement of cultural themes across the border between work and politics.

\section{APPENDIX: CODING CATEGORIES (FIRST TWO OF THREE LEVELS)}

000: Source

10-Fortune

20-Business Week

30-Commercial and Financial Chronicle

40-Iron Age

${ }^{10}$ The periodization developed by Barley and Kunda, described earlier, offers a good starting point. 
100: Provides amenities not strictly related to specific jobs

110 - equalitarian style

120 - physical environment

130_charismatic boss, fun/inspiring to work for, etc.

140 — welfare benefits (pensions, accident insurance, etc.)

200: Good governance

210 - rule of law/fairness/consistency in dealing with employees

220 -improving communication between ranks

230 — decentralizing organization/flattening hierarchy

240-bureaucratizing

250 - participation/cooperation (actually involving workers in decisionmaking)

260 - decent/respectful treatment

270 - getting rid of union

300: Building better workplace community

310 - binding individual to firm

320 -employee ownership/buyouts (if emphasis is on company community, not incentives)

330 - enhancing diversity (e.g., company day care, facilities for disabled) 340-building company culture (common goals, esprit de corps, enthusiasm)

350 - teamwork (among individuals at similar levels)

360 - improving character (vs. technical skills) of employees (programs for this)

400: Fostering individual opportunity/output

410_upgrading worker skills

420 - flexibility in job tasks

430 - improving rewards for individual contributions

440-decentralizing responsibility, encouraging entrepreneurialism, risk-taking, innovation

450_improving facilities/resources for job performance

500: What else are they commended for

510 - community service

520 - good family member

530 — making company more successful/profitable

540 - technical prowess/innovation

550 - productivity/output (quantity)

560_quality/service

570 - political influence

580 - keeping unions out

590_reduces strikes/conflict/bad feelings (as bonus from other 
practices)

595-improving character or morals of workforce

600: What specific industry

610-manufacturing

620-services

630_railroads

700: What kinds of employees are targeted

710_blue collar

720 - white collar

730_all/mixed

800: Size of firm

900: Who is getting credit

910-owner

920-manager

930 - company and union

940 - not specified

1000: Year

\section{ACKNOWLEDGMENTS}

We thank Kathy Mooney, John Skrentny, Akos Rona-Tas, Paul Frymer, Dan Cornfield, and the anonymous reviewers for their comments. The University of California's Institute for Labor and Employment generously provided financial support.

\section{REFERENCES}

\section{Abrahamson, Eric}

1997 "The emergence and prevalence of employee management rhetorics: The effects of long waves, labor unions, and turnover, 1875-1992." Academy of Management Journal 40:491-533.

\section{Akard, Patrick J.}

1992 "Corporate mobilization and political power: The transformation of U.S. economic policy in the 1970s." American Sociological Review 57:597-615.

\section{Barley, S. R., and G. Kunda}

1992 "Design and devotion: Surges of rational and normative ideologies of control in managerial discourse." Administrative Science Quarterly 37:363399.
Baron, James, Frank Dobbin, and P. Devereaux Jennings

1986 "War and peace: The evolution of modern personnel administration in U.S. industry." American Journal of Sociology 92:350-383.

\section{Beckert, Sven}

2001 The Monied Metropolis: New York City and the Consolidation of the American Bourgeoisie, 1850-1896. Cambridge, England: Cambridge University Press.

Beisel, Nicola

1997 Imperiled Innocents: Anthony Comstock and Family Reproduction in Victorian America. Princeton, NJ: Princeton University Press. 


\section{Bendix, Reinhard}

1974 Work and Authority in Industry: Ideologies of Management in the Course of Industrialization. Berkeley and Los Angeles: University of California Press.

Blackford, Mansel G.

1993 The Lost Dream: Businessmen and City Planning on the Pacific Coast 1890-1920. Columbus, OH: Ohio State University Press.

Bonnett, Clarence E.

1956 History of Employers' Associations in the United States. New York: Vantage Press.

Boyer, Paul

1978 Urban Masses and Moral Order in America, 1820-1920. Cambridge, MA: Harvard University Press.

\section{Brandes, Stuart}

1976 American Welfare Capitalism 1880 1940. Chicago: University of Chicago Press.

\section{Buenker, John}

1973 Urban Liberalism and Progressive Reform. New York: Charles Scribner's Sons.

Calvert, Monte A.

1967 The Mechanical Engineer in America, 1830-1910: Professional Cultures in Conflict. Baltimore: Johns Hopkins Press.

Clemens, Elisabeth $\mathbf{S}$.

1997 The People's Lobby: Organizational Innovation and the Rise of Interest Group Politics in the United States, 1890-1925. Chicago: University of Chicago Press.

\section{Cochran, Thomas}

1972 Business in American Life: A History. New York: McGraw-Hill.

Derthick, Martha, and Paul J. Quirk

1985 The Politics of Deregulation. Washington, DC: Brookings Institution.

\section{DiMaggio, Paul}

1997 "Culture and cognition." Annual Review of Sociology 23:263287.

Dobbin, Frank

1994 Forging Industrial Policy: The United States, Britain, and France in the Railway Age. Cambridge, England: Cambridge University Press.

\section{Edsall, Thomas Byrne}

1989 "The changing shape of power: A realignment in public policy." In Steve Fraser and Gary Gerstle (eds.), The Rise and Fall of the New Deal Order, 1930-1980: 269-293. Princeton, NJ: Princeton University Press.

Edsall, Thomas Byrne, and Mary D. Edsall

1991 Chain Reaction: The Impact of Race, Rights, and Taxes on American Politics. New York: W.W. Norton.

\section{Eggert, Gerald G.}

1993 Harrisburg Industrializes: The Coming of Factories to an American Community. University Park, PA: Pennsylvania University Press.

Ferguson, Eugene $\mathrm{S}$.

1989 "Technical journals and the history of technology." In Stephen H. Cutcliffe and Robert C. Post (eds.), In Context: History and the History of Technology: 53-70. London and Toronto: Associated University Presses.

\section{Fox, Kenneth}

1977 Better City Government: Innovation in American Urban Politics, 18501937. Philadelphia, PA: Temple University Press.

Fraser, Steve, and Gary Gerstle (eds.)

1989 The Rise and Fall of the New Deal Order, 1930-1980. Princeton, NJ: Princeton University Press.

\section{Gilkeson, John S., Jr.}

1986 Middle-Class Providence, 1820-1940. Princeton, NJ: Princeton University Press.

\section{Guillén, Mauro F.}

1994 Models of Management: Work, Authority, and Organization in a Comparative Perspective. Chicago: University of Chicago Press.

\section{Haber, Samuel}

1964 Efficiency and Uplift: Scientific Management in the Progressive Era, 1890 1920. Chicago: University of Chicago Press.

\section{Haydu, Jeffrey}

2002 "Business citizenship at work: Cultural transposition and class formation in Cincinnati, 1870-1910.” American Journal of Sociology 107:14241467.

Hays, Samuel P.

1964 "The politics of reform in municipal government in the Progressive Era." 
Pacific Northwest Quarterly 55:157169.

Hoffecker, Carol E.

1974 Wilmington, Delaware: Portrait of an Industrial City, 1830-1910. Charlottesville, VA: University Press of Virginia.

\section{Hofstadter, Richard}

1955 The Age of Reform. New York: Vintage Books.

\section{Horowitz, Helen Lefkowitz}

1976 Culture and the City: Cultural Philanthropy in Chicago From the 1880s to 1917. Lexington, KY: University Press of Kentucky.

Howard, Philip K.

1994 The Death of Common Sense: How Law Is Suffocating America. New York: Random House.

Ingham, John N.

1978 The Iron Barons: A Social Analysis of an American Urban Elite, 1874-1965. Westport, CT: Greenwood Press.

1991 Making Iron and Steel: Independent Mills in Pittsburgh, 1820-1920. Columbus, OH: Ohio State University Press.

Jacoby, Sanford M.

1985 Employing Bureaucracy: Managers, Unions, and the Transformation of Work in American Industry, 19001945. New York: Columbia University Press.

Kaufman, Bruce E.

1993 The Origins and Evolution of the Field of Industrial Relations in the United States. Ithaca, NY: Cornell University Press.

Kazin, Michael

1995 The Populist Persuasion: An American History. New York: Basic Books.

\section{Mandell, Nikki}

1997 "A human contact mechanism: The corporate welfare system and the gendering of labor management, 18901930." PhD Dissertation, University of California-Davis.

Mapes, Lynn Gordon

1973 "Iron age: An iron manufacturers' journal and the 'labor problem' in the age of enterprise." PhD Dissertation,

\section{Marchand, Roland} University of Rochester.

1998 Creating the Corporate Soul: The Rise of Public Relations and Corporate
Imagery in American Big Business. Berkeley and Los Angeles: University of California Press.

\section{McGirr, Lisa}

2001 Suburban Warriors: The Origins of the New American Right. Princeton, NJ: Princeton University Press.

Miller, Zane L.

1968 Boss Cox's Cincinnati: Urban Politics in the Progressive Era. New York: Oxford University Press.

\section{Nelson, Daniel}

1975 Managers and Workers: Origins of the New Factory System in the United States, 1880-1920. Madison, WI: University of Wisconsin Press.

\section{Noble, David}

1977 America by Design: Science, Technology, and the Rise of Corporate Capitalism. New York: Alfred A. Knopf.

\section{Osborne, David}

1988 Laboratories of Democracy. Boston: Harvard Business School Press.

\section{Phillips, Kevin}

1983 Post-Conservative America: People, Politics, and Ideology in a Time of Crisis. New York: Vintage Books.

Piore, Michael J., and Charles F. Sabel

1984 The Second Industrial Divide: Possibilities for Prosperity. New York: Basic Books.

\section{Ramirez, Bruno}

1978 When Workers Fight: The Politics of Industrial Relations in the Progressive Era, 1898-1916. Westport, CT: Greenwood Press.

Roberts, Carl W. (ed.)

1997 Text Analysis for the Social Sciences: Methods for Drawing Statistical Inferences From Texts and Transcripts. Mahway, NJ: Erlbaum.

\section{Ross, Steven J.}

1985 Workers on the Edge: Work, Leisure, and Politics in Industrializing Cincinnati, 1788-1890. New York: Columbia University Press.

\section{Schiesl, Martin J.}

1977 The Politics of Efficiency: Municipal Administration and Reform in America, 1800-1920. Berkeley and Los Angeles: University of California Press. 


\section{Schloss, David F.}

1898 Methods of Industrial Remuneration, 3rd edn. London: Williams and Norgate.

Schwartz, Michael (ed.)

1987 The Structure of Power in America: The Corporate Elite as a Ruling Class. New York: Holmes and Meier.

\section{Shenhav, Yehouda}

1995 "From chaos to systems: The engineering foundations of organization theory, 1879-1932." Administrative Science Quarterly 40:557-585.

1999 Manufacturing Rationality: The Engineering Foundations of the Managerial Revolution. New York: Oxford University Press.

\section{Sproat, John G.}

1968 "The Best Men": Liberal Reformers in the Gilded Age. New York: Oxford University Press.

\section{Steeples, Douglas}

2002 Advocate for American Enterprise: William Buck Dana and the Commercial and Financial Chronicle, 1865-

Stockman, David 1910. Westport, CT: Greenwood Press.

1986 The Triumph of Politics: How the Reagan Revolution Failed. New York: Harper and Row.

\section{Thelen, David P.}

1972 The New Citizenship: Origins of Progressivism in Wisconsin, 1885-1900. Columbia, MO: University of Missouri Press.

\section{Useem, Michael}

1987 "The inner circle and the political voice of business." In Michael Schwartz (ed.), The Structure of Power in America: The Corporate Elite as a Ruling Class: 143-153. New York: Holmes and Meier.

Watts, Sarah Lyons

1991 Order Against Chaos: Business Culture and Labor Ideology in American, 1880-1915. New York: Greenwood Press.

\section{Weber, Robert Philip}

1990 Basic Content Analysis. Newbury Park, CA: Sage.

\section{Wiebe, Robert $\mathrm{H}$.}

1962 Businessmen and Reform: A Study of the Progressive Movement. Cambridge, MA: Harvard University Press.

\section{Zunz, Olivier}

1990 Making America Corporate, 18701920. Chicago: University of Chicago Press. 